\title{
FIRST RECORD OF JUNCUS ARTICULATUS SUBSP. articulatus (JunCACEAE) FOR THE SOUTHERN CONE FLORA
}

\author{
PRIMER REGISTRO DE JUNCUS ARTICULATUS SUBSP. ARTICULATUS \\ (JunCACEAE) PARA LA Flora Del Cono Sur
}

\author{
Adriel I. Jocou ${ }^{1 *(\mathbb{D})}$ and Nicolás F. Brignone ${ }^{2}$ (D)
}

1. Departamento de Biología Aplicada, Facultad de Ciencias Agrarias. Universidad Nacional del Comahue. RN N ${ }^{\circ} 151 \mathrm{~km} \mathrm{12,5,}$ CC 85, CP 8303, Cinco Saltos, Río Negro, Argentina.

2. Instituto de Botánica Darwinion (IBODA, CONICET-ANCEFN), Labardén 200, CC 22, CP 1642, San Isidro, Buenos Aires, Argentina.

*adrieljocou@gmail.com

\section{Citar este artículo} JOCOU, A. I. \& N. F. BRIGNONE. 2020. First record of Juncus articulatus subsp. articulatus (Juncaceae) for the Southern Cone flora. Bol. Soc. Argent. Bot. 55: 631-640.

DOI: https://doi. org/10.31055/1851.2372.v55. n4.29938

Recibido: 15 Ago. 2020

Aceptado: 17 Sep. 2020

Publicado en línea: 13 Nov. 2020

Publicado impreso: 20 Dic. 2020

Editora: Carolina I. Calviño (DD

\section{SUMMARY}

Background and aims: Juncus is the largest and most diverse genus of Juncaceae, distributed mainly in the temperate zones of both hemispheres. The Southern Cone flora contains ca. 38 Juncus species (44 taxa including 12 infraspecific categories). Sixteen of those species belong to the section Ozophyllum. As a part of our ecologic studies in wetlands of Patagonia (Argentina) we collected specimens of Juncus that did not match any of the species currently known to the Southern Cone. The aim of this contribution is to report for the first time the presence of Juncus articulatus subsp. articulatus for the Southern Cone flora.

M\&M: Classical methods in taxonomy were employed. Living and herbarium material, original descriptions, and type material of Juncus articulatus subsp. articulatus were studied. Collected materials were deposited in the herbarium ARC of the Universidad Nacional del Comahue.

Results: Juncus articulatus subsp. articulatus is here described. A distribution map, photos, and a key to the Southern Cone species of Juncus belonging to the section Ozophyllum are provided. Also, some ecological and distributional features are discussed.

Conclusions: The naturalization of Juncus articulatus subsp. articulatus is reported here for the first time in the Southern Cone. From now on, Juncus contributes 39 species to the Southern Cone flora, and 17 to Juncus section Ozophyllum.

\section{KEY WORDS}

Flora of Argentina, Juncus, new record, Ozophyllum, South America, wetlands.

\section{RESUMEN}

Introducción y objetivos: Juncus es el género más grande y diverso de Juncaceae, distribuido en zonas templadas de ambos hemisferios. La flora del Cono Sur contiene ca. 38 especies de Juncus (44 taxones que incluyen 12 categorías infraespecíficas). Dieciséis de esas especies pertenecen a la sección Ozophyllum. Como parte de nuestros estudios ecológicos en humedales de la Patagonia (Argentina), hemos coleccionado especímenes de Juncus que no coincidían con ninguna de las especies actualmente conocidas en el Cono Sur. El objetivo de esta contribución es reportar por primera vez la presencia de Juncus articulatus subsp. articulatus para la flora del Cono Sur.

M\&M: Se emplearon los métodos clásicos de taxonomía. Se estudió material vivo y de herbario, descripciones originales y material tipo de Juncus articulatus subsp. articulatus. El material coleccionado fue depositado en el herbario ARC de la Universidad Nacional del Comahue.

Resultados: Se describe a Juncus articulatus subsp. articulatus. Se proporciona un mapa de distribución, fotografías y una clave de las especies de Juncus pertenecientes a la sección Ozophyllum presentes en el Cono Sur. Se discuten algunas características ecológicas y de distribución de la especie.

Conclusiones: Se reporta por primera vez la naturalización de Juncus articulatus subsp. articulatus en el Cono Sur. Desde ahora, Juncus aporta 39 especies a la flora del Cono Sur y 17 a la sección Ozophyllum.

\section{Palabras clave}

Flora Argentina, humedales, Juncus, nuevo registro, Ozophyllum, Sudamérica. 


\section{INTRODUCTION}

Juncaceae Juss. is a cosmopolitan family, comprising seven genera and ca. 440 species (Stevens, 2001 onwards; Kirschner, 2002a). Rushes are mainly distributed in temperate and polar regions in both hemispheres, commonly in the subtropics, inhabiting the mountains (Kirschner, 2002a; Drábková et al., 2006). Juncus L. (ca. 315 spp.), and Luzula DC. (ca. 115 spp.) are the most widespread genera in the family, whereas Marsippospermum Desv. (four species) and Rostkovia Desv. (two species) are found in New Zealand, South America and on some southern hemisphere islands. Oxychloë Phil. (five species), Patosia Buchenau (one species), and Distichia Nees \& Meyen (three species) are restricted to the Andes of South America.

The genus Juncus is distributed mainly in both the northern and southern hemispheres, but rare in the tropics (Balslev, 1996; Kirschner, 2002b; Romero Zarco, 2010). Two subgenera and 10 sections are currently recognized (Kirschner, 2002b): subg. Juncus (six sections), and subg. Agathryon Raf. (four sections; Table 1). The Southern Cone flora (Argentina, south of Brazil, Chile, Paraguay, and Uruguay) harbours ca. 38 species, and 12 infraspecific taxa of Juncus, summing for a total of 44 taxa (Zuloaga et al., 2019). Sixteen of those 38 species belong to the sect. Ozophyllum Dumort. (Table 1). The mainly terete leaves that are unitubulose or pluritubulose, and perfectly septate, constitute the synapomorphies of this section (Kirschner, 2002b).

Juncus articulatus L. belongs to sect. Ozophyllum (sensu Kirschner, 2002b), and it is considered an extremely variable species, so its description turning difficult in terms of infraspecific taxa. In this sense, Kirschner (2002b) recognizes only two subspecies: subsp. articulatus, and subsp. limosus (Vorosch.) Vorosch. The typical subspecies is one of the most widely distributed taxa in Juncus; it is frequent in Asia, Europe, North of Africa, North America, also Australia, New Zealand, South Africa, and Peru (Balslev, 1996; Kirschner, 2002b; Romero Zarco, 2010). Juncus articulatus subsp. limosus is restricted to the Far East, being most common in the Amur and Khabarovsk regions, and the adjacent regions of Chinese Manchuria (Kirschner, 2002b).
As a part of our ecological and floristic studies in the wetlands of Patagonia, Argentina (Fernández et al., 2018; Jocou \& Gandullo, 2018; Jocou et al., 2018; Gandullo et al., 2019; Jocou \& Gandullo, 2020; Jocou et al., 2020), we collected specimens of Juncus that did not match the features to any of the species currently known to the Southern Cone. The aim of this contribution is to report for the first time the presence of Juncus articulatus subsp. articulatus for the Southern Cone flora, by the study of living and herbarium material, original descriptions, type material, and complementing with a distribution map, photos, and a key to the sect. Ozophyllum for the Southern Cone. Also, some ecological and distributional features are discussed.

\section{MATERIALs AND METHOdS}

Previous works on the genus Juncus in the region were consulted (Barros, 1945; Barros, 1953; Barros, 1969; Balslev, 1996; Novara, 2009; Balslev, 2018; Zuloaga et al., 2019). Classical methods in taxonomy were employed. The taxonomic identity of the collected specimens was established following Balslev (1996), Kirschner (2002b), and Romero Zarco (2010). The collected specimens were also compared with the high resolution images of the lectotype kept at $\mathrm{L}$ herbarium (herbarium acronyms following Thiers, 2020), and with available descriptions of $J$. articulatus, and the subsp. articulatus (Nilsson \& Snogerup, 1972; Balslev, 1996; Brooks \& Clemants, 2000; Guofang \& Clemants, 2000; Kirschner, 2002b; Romero Zarco, 2010). Some additional material from P, SI, US and WTU belonging to North American and European $J$. articulatus subsp. articulatus were also studied for comparison. All the specimens collected of $J$. articulatus subsp. articulatus were deposited in ARC. The number indicated for the lectotype belongs to the barcode of the specimen.

The morphological study of the specimens was performed under a stereomicroscope Leica EZ4 HD, and the photographs were taken using LAS EZ 3.4.0. The distribution map for the Southern Cone (Fig. 1) was created in QGIS 3.14 "Pi" (QGIS Development Team, 2020) using the GPS coordinates from the collected specimens. 


\section{A. I. Jocou and N. F. Brignone - Juncus articulatus in the Southern Cone}

Table 1. Summary of subgenera and sections within Juncus, as well as the number of species in each section and their distributions worldwide, and the number and species per section in the Southern Cone flora. The * indicates the total number of species within section Ozophyllum, including the new record of J. articulatus subsp. articulatus.

\begin{tabular}{|c|c|c|c|c|}
\hline Subgenus & Section & $\begin{array}{l}\text { Number } \\
\text { of species } \\
\text { in the } \\
\text { world }\end{array}$ & Distribution & $\begin{array}{l}\text { Number and species in the } \\
\text { Southern Cone Flora }\end{array}$ \\
\hline \multirow{4}{*}{$\begin{array}{l}\text { Agathryon } \\
\text { Raf. }\end{array}$} & $\begin{array}{l}\text { Forskalina } \\
\text { Kuntze }\end{array}$ & 1 & $\begin{array}{l}\text { Distributed in the whole Mediterra- } \\
\text { nean region. }\end{array}$ & not represented \\
\hline & $\begin{array}{l}\text { Juncotypus } \\
\text { Dumort. }\end{array}$ & 67 & $\begin{array}{l}\text { World-wide distribution. Mainly } \\
\text { in Australia and Pacific North } \\
\text { America. }\end{array}$ & $\begin{array}{l}\text { 8: Juncus balticus Willd.; J. } \\
\text { conglomeratus L.; J. effusus L.; } \\
\text { J. filiformis L.; J. kleinii Barros; J. } \\
\text { procerus E.Mey.; J. ramboi Barros; J. } \\
\text { uruguensis Griseb. }\end{array}$ \\
\hline & $\begin{array}{l}\text { Steirochloa } \\
\text { Griseb. }\end{array}$ & 35 & $\begin{array}{l}\text { Widespread, with species native } \\
\text { to all temperate regions except for } \\
\text { South Africa. Mainly in } W \text { and } E \\
\text { North America, Central Asia and } \\
\text { temperate South America. }\end{array}$ & $\begin{array}{l}\text { 7: Juncus capillaceus Lam.; J. } \\
\text { cordobensis Barros; J. dichotomus } \\
\text { Elliott; J. homalocaulis F.Muell. ex } \\
\text { Benth.; J. imbricatus Laharpe; J. } \\
\text { tenuis Willd.; J. venturianus Castillón }\end{array}$ \\
\hline & $\begin{array}{l}\text { Tenageia } \\
\text { Dumort. }\end{array}$ & 11 & $\begin{array}{l}\text { W of Mediterranean region; some } \\
\text { species very widespread. }\end{array}$ & 1: Juncus bufonius L. \\
\hline \multirow{6}{*}{ Juncus } & $\begin{array}{l}\text { Caespitosi } \\
\text { Cout. }\end{array}$ & 16 & Southern Africa, W North America. & 1: Juncus capitatus Weigel \\
\hline & $\begin{array}{l}\text { Graminifolii } \\
\text { Engelm. }\end{array}$ & 22 & $\begin{array}{l}\text { W North America, southern Africa, } \\
\text { Australasian region. }\end{array}$ & $\begin{array}{l}\text { 3: Juncus cyperoides Laharpe; J. } \\
\text { marginatus Rostk.; J. planifolius R.Br. }\end{array}$ \\
\hline & $\begin{array}{l}\text { Iridifolii } \\
\text { Snogerup \& } \\
\text { Kirschner }\end{array}$ & 10 & W North America, Eastern Asia. & not represented \\
\hline & Juncus & 9 & $\begin{array}{l}\text { Not geographically circumscribed. } \\
\text { It includes species from Europe, } \\
\text { America, Africa and East Asia. }\end{array}$ & $\begin{array}{l}\text { 2: Juncus acutus L.; J. kraussii } \\
\text { Hochst. }\end{array}$ \\
\hline & $\begin{array}{l}\text { Ozophyllum } \\
\text { Dumort. }\end{array}$ & 86 & $\begin{array}{l}\text { E North America, South America, } \\
\text { SW Europe, the Far East, North } \\
\text { Africa, S Africa, Oceania. }\end{array}$ & $\begin{array}{l}17^{*} \text { : Juncus articulatus } \\
\text { L. subsp. articulatus; } \\
\text { Juncus acuminatus Michx.; } \\
\text { J. andersonii Buchenau; J. } \\
\text { austrobrasiliensis Balslev; J. } \\
\text { brasiliensis Breistr.; J. bulbosus L.; } \\
\text { J. burkartii Barros; J. debilis A.Gray; } \\
\text { J. densiflorus Kunth; J. diemii } \\
\text { Barros; J. ernesti-barrosii Barros; J. } \\
\text { llanquihuensis Barros; J. micranthus } \\
\text { Schrad. ex E.Mey.; J. microcephalus } \\
\text { Kunth (incl. J. involucratus Steud. } \\
\text { ex Buchenau); J. pallescens Lam.; } \\
\text { J. scheuchzerioides Gaudich.; J. } \\
\text { stipulatus Nees \& Meyen }\end{array}$ \\
\hline & $\begin{array}{l}\text { Stygiopsis } \\
\text { [Grand. ex] } \\
\text { Kuntze }\end{array}$ & 59 & $\begin{array}{l}\text { In high mountains of North } \\
\text { Hemisphere and subarctic } \\
\text { regions, centred in the Sino- } \\
\text { Himalaya. }\end{array}$ & not represented \\
\hline
\end{tabular}




\section{Results AND Discussion}

Juncus articulatus L., Sp. Pl. 1: 327. 1753. subsp. articulatus. TYPE: Herb. A. van Royen, L N ${ }^{\circ}$ 904.145-409 (Lectotype L 0221767 [photo!] designated by Ferrer-Gallego, 2019). Figs. 2-4.

Herbs, perennial, usually caespitose, $10-55 \mathrm{~cm}$ tall. Rhizome short, short-creeping, rarely with nodes elongated, $2-3 \mathrm{~mm}$ diam., not swollen. Stems usually erect, sometimes decumbent, submerged or growing in moving sand and rooting at nodes, terete, $1-3.5 \mathrm{~mm}$ diam., smooth. Cataphylls usually 1 , rarely 2 , maroon to straw-coloured, apex acute to obtuse. Cauline leaves 2-6, usually 3; leaf sheath auricles well developed, free part $0.5-2$ $\mathrm{mm}$, membranous, apex rounded, scarious; leaf blade green to straw-coloured, terete, 3-17 cm long, 0.5-2 $\mathrm{mm}$ wide, subacute, unitubulose, with perfect septa that are conspicuous externally. Inflorescences decompound, 2-12 long, 1.5-6 $\mathrm{cm}$ wide, terminal panicles of 6-55, obpyramidal

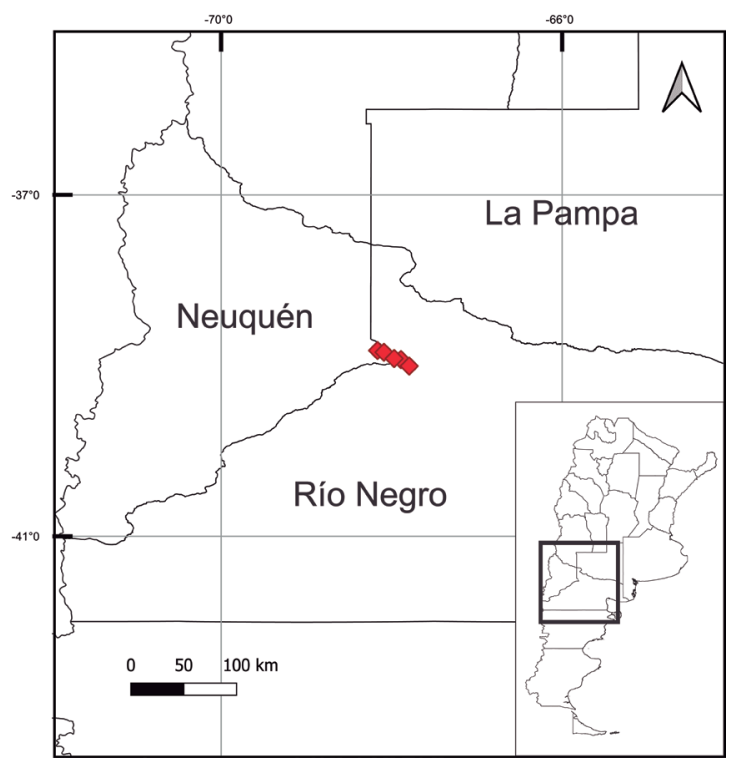

Fig. 1. Juncus articulatus subsp. articulatus. Geographic location of collected specimens in Argentina.
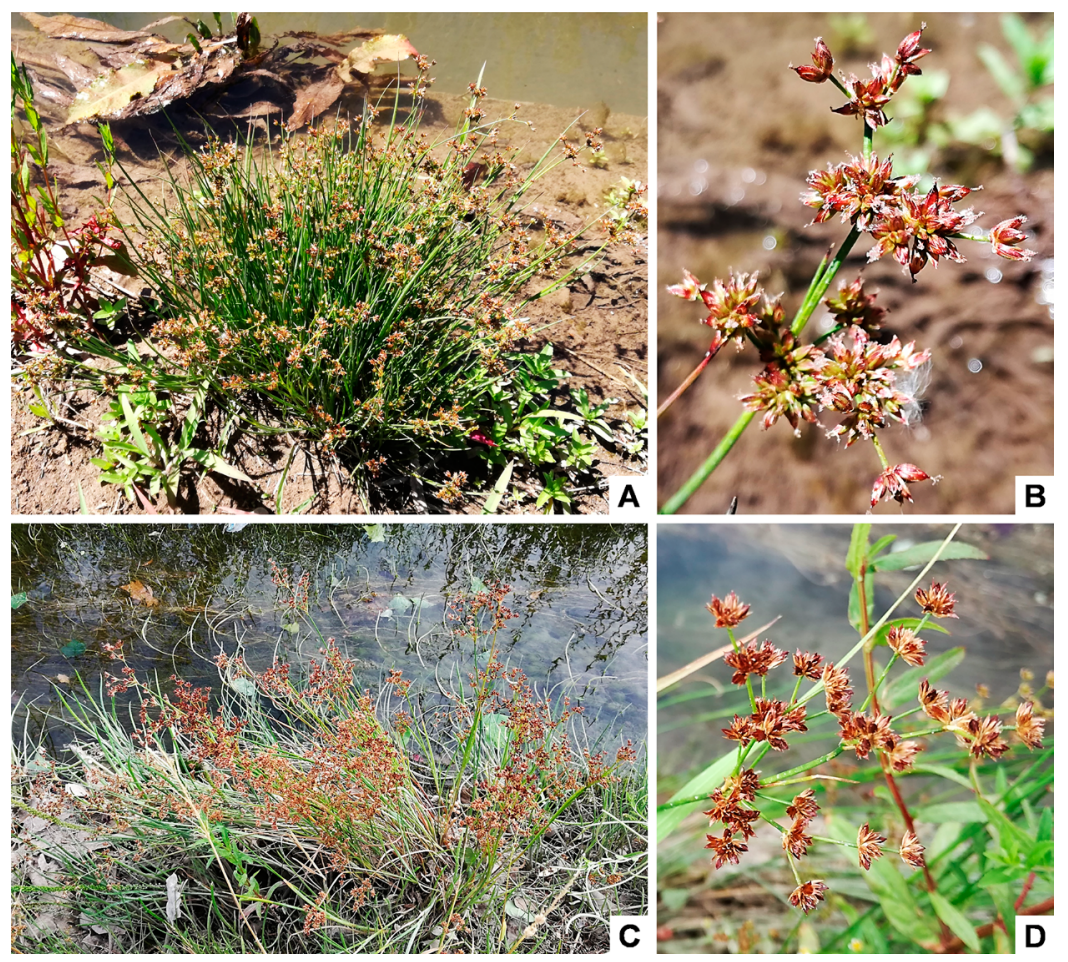

Fig. 2. Juncus articulatus subsp. articulatus. A: Plant on urban irrigation canal in Allen, Río Negro province (Jocou et al. 2314). B: Inflorescence (Jocou et al. 2314). C: Plant on rural irrigation canal in General Fernández Oro, Río Negro province (Jocou 2317). D: Inflorescence (Jocou 2317). 


\section{A. I. Jocou and N. F. Brignone - Juncus articulatus in the Southern Cone}

to hemispheric, 4-10-flowered heads, each head 3-4 mm long, 3-9 mm wide; branches spreading, erectopatent; primary bract erect, shorter than the inflorescence, $1.5-4 \mathrm{~cm}$ long. Tepals maroon or straw-coloured, completely brown or with a green central band, ovate to lanceolate, usually equal, 2.5-3 mm long, $0.7-1.1 \mathrm{~mm}$ wide; outer tepals sometimes slightly longer, carinate, more or less narrowly bordered, varying in colour from green dorsally with darker lateral bands and apex dark brown or castaneous-coloured, acute or rarely subobtuse and mucronate; inner tepals obtuse to acute, mucronate, with distinct scarious margins. Stamens 6, anthers ca. $1 \mathrm{~mm}$ long, equalling filaments, rarely slightly longer or shorter. Style 0.3-0.7 mm long, stigmas to $1.5 \mathrm{~mm}$ long. Capsule exserted $0.5-1.5 \mathrm{~mm}$ beyond perianth, trigonous, ellipsoid or ovoid, imperfectly 3-locular, 3.8-4.2 $\mathrm{mm}$ long, castaneous to dark brown, glossy, apex acute proximal to beak, valves separating and apex slightly reflexed at dehiscence; rostrum ca. $0.3-0.5$ $\mathrm{mm}$ long. Seeds obovoid, $0.5-0.7 \mathrm{~mm}$ long, reticulate, not tailed, yellowish, one of the ends dark brown coloured.

References. See Kirschner (2002b) for list of synonyms.

Iconography. Bauhin (1620: 12; 1658: 75, 76); Brooks \& Clemants (2000: 253); Thomé (1886: pl. 107); Guofang \& Clemants (2000: Fig. 42 [9-12]); Kirschner (2002b: 253, Fig. 109); Morison (1699: sect. 8, t. 9, Fig. 1); Nilsson \& Snogerup (1972: [136]-137, Fig. 74).

Distribution. Widespread: North of Africa, Asia, Europe, North America and South America, also in Australia, New Zealand, and South Africa (Nilsson \& Snogerup, 1972; Brooks \& Clemants, 2000; Kirschner, 2002b; Romero Zarco, 2010).

In South America, Juncus articulatus were first reported by Balslev (1996) only for Peru. The presence in the Southern Cone is reported here for the first time, growing in Argentina, particularly in Neuquén and Río Negro provinces (Fig. 1).

Habitat. Juncus articulatus subsp. articulatus inhabits various moist and wet natural or man-made places, margins of watercourses, usually on acid soils, often behaving like calcicole (Grime et al.,

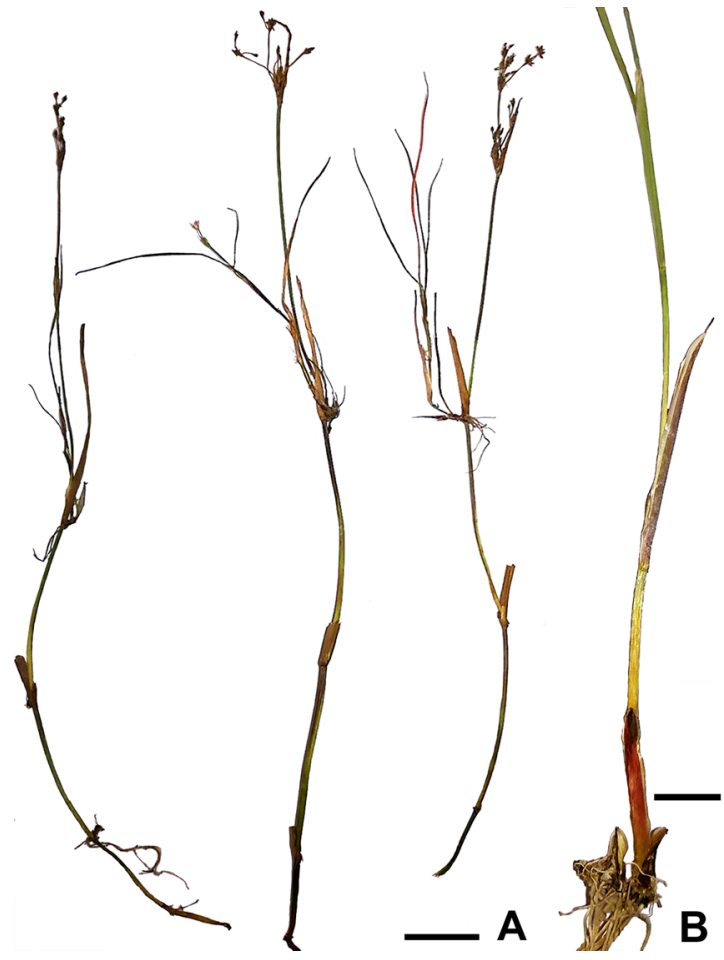

Fig. 3. Juncus articulatus subsp. articulatus, vegetative features. A: Specimens rooting at basal and upper nodes (Jocou 2316). B: Presence of cataphylls in the lower area of the stem (Jocou 2317). Scales $=A: 3 \mathrm{~cm}, B: 2 \mathrm{~cm}$.

1988; Brooks \& Clemants, 2000; Kirschner, 2002b; Ferrer-Gallego, 2019); 0-3700 m (Guofang \& Clemants, 2000; Brooks \& Clemants, 2000).

In Argentina, Juncus articulatus was found growing on river banks (Neuquén River), also in flooded or wet soils of man-made irrigation canals (Fig. 2AD). It has not been observed in drainage channels. Along irrigation canals, this subspecies grows with Bidens pilosa L. var. pilosa (Asteraceae), Epilobium ciliatum Raf. (Onagraceae), Juncus microcephalus Kunth (Juncaceae), Lilaeopsis occidentalis J.M. Coult. \& Rose (Apiaceae), Plantago australis Lam. subsp. australis (Plantaginaceae), Polypogon viridis (Gouan) Breistr (Poaceae), and Triglochin striata Ruiz \& Pav. (Juncaginaceae). On river banks, it grows with Plantago australis subsp. australis, Cyperus eragrostis Lam. var. eragrostis (Cyperaceae), Eleocharis bonariensis Nees (Cyperaceae), E. radicans (Poir.) Kunth (Cyperaceae), Mentha 

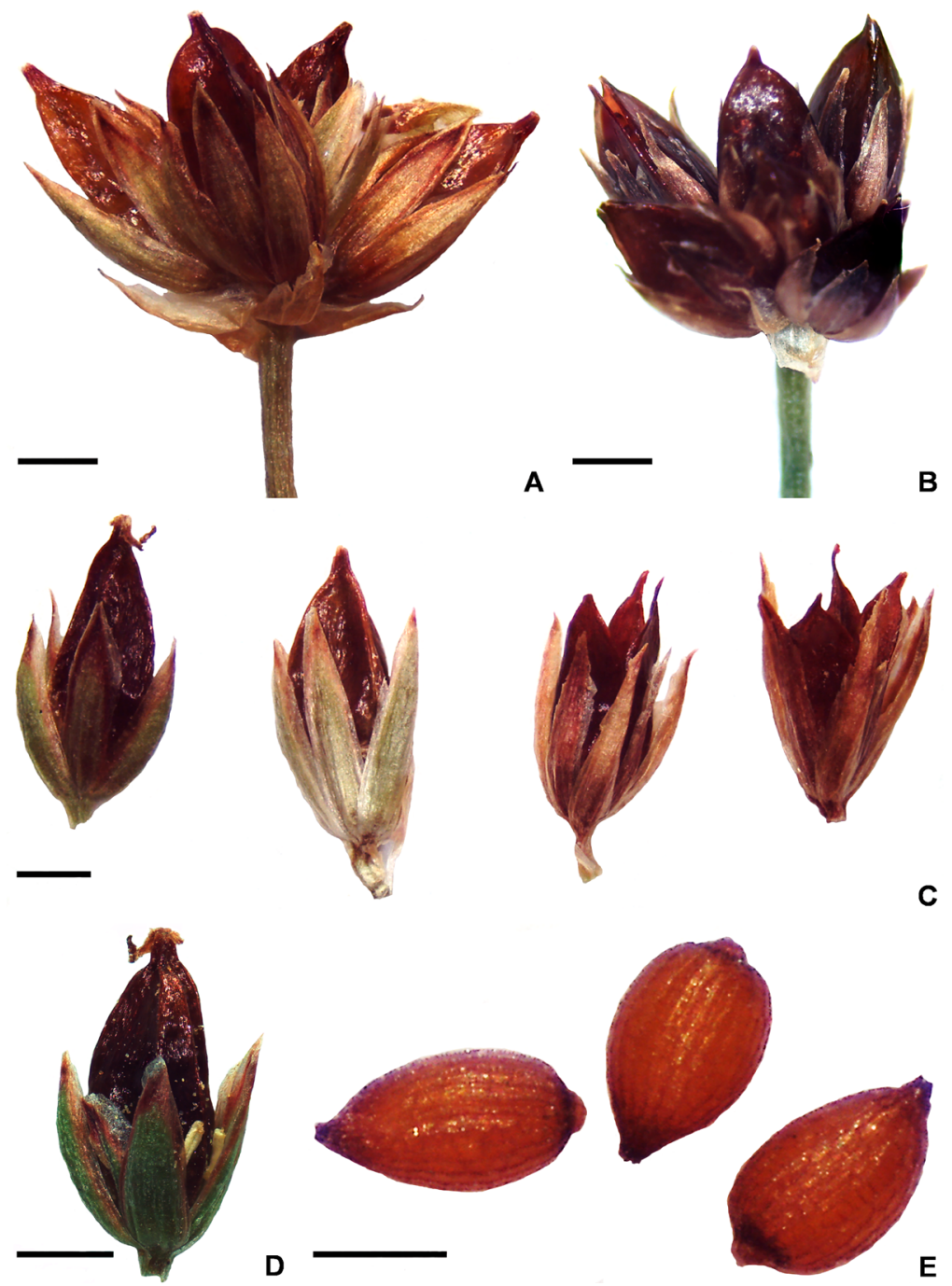

Fig. 4. Juncus articulatus subsp. articulatus, reproductive features. A-B: Flowered-head (Jocou et al. 2314, Jocou 2317, respectively). C: Colour variability of the tepals, and different maturity stages of capsules (Jocou \& Minué 2313, Jocou et al. 2314, Jocou 2316, Jocou 2317, respectively). D: Details of capsule and remnants of the flower (Jocou \& Minué 2313). E: Seeds (Jocou 2316). Scales= A-D: $1 \mathrm{~mm}, \mathrm{E}: 0.25 \mathrm{~mm}$.

pulegium L. (Lamiaceae), Polypogon australis Brongn. (Poaceae), and P. elongatus Kunth var. elongatus (Poaceae). We observed that this taxon roots even at the last node of the stem, generating new plants and promoting colonization of the habitat through asexual reproduction (Fig. 3A).

Observations. The water level dynamics and soil nutrients promote a high morphological plasticity (Grime et al., 1988). As expected, Juncus articulatus is an extremely variable species with a high morphological diversity (Ferrer-Gallego, 2019), so its infraspecific delimitation is difficult, and further studies are needed (Kirschner, 2002b). Following Kirschner (2002b), the characters of the specimens collected and examined for this paper belong to the subsp. articulatus, with tepals to 3 $\mathrm{mm}$ long, equal, completely brown or with a green central band (never totally green, Fig. 4 A-D), and anthers equalling the filaments. 


\section{A. I. Jocou and N. F. Brignone - Juncus articulatus in the Southern Cone}

Vogt et al. (2004) confirmed that the dispersal of Juncus seeds occurs through water, and then they are deposited in the sediments. Consequently, the presence of this taxon on the banks of the Neuquén River, and along the irrigation canals in the Río Negro province may not be a mere coincidence. The irrigation water comes from artificial reservoirs of the Neuquén River, being able to transport the seeds (Fig. 4E) over long distances, promoting the distribution of the species along other rivers and irrigation canals, among other interconnected aquatic environments. In this case, the populations found were perfectly established at a distance of more than $30 \mathrm{~km}$ from each other. Consequently, and adding the capacity of its seeds to remain viable for at least 12 years (Geoffrey et al., 1996; Smith \& Brock, 1997; Roberts \& Marston, 2000), Juncus articulatus subsp. articulatus can be considered as naturalized in Argentina, according to Pyšek et al. (2004).

\section{Conclusions}

The naturalization of Juncus articulatus subsp. articulatus is reported for the first time in the Southern Cone. From this contribution, the circumscription of Juncus sect. Ozophyllum to the Southern Cone is here expanded, including Juncus articulatus. Summing up, Juncus comprises 39 species to the Southern Cone flora, and 17 in sect. Ozophyllum.

Due to the widespread distribution of Juncus articulatus subsp. articulatus around the world, further studies might reveal additional occurrences in the Southern Cone.

\section{Key to the Southern Cone species of Juncus belonging to the section Ozophyllum}

1. Leaves bitubulose to pluritubulose.

J. bulbosus

1 '. Leaves unitubulose.

2. Stamens usually 3 .

3. Plants rhizomatous; rhizomes creeping, with internodes usually at least $0.5 \mathrm{~cm}$ long or longer, or rhizomes ascending-branching.

4. Flower heads dark brown.

5. Capsule more or less equalling the perianth.

J. brasiliensis

5'. Capsule clearly longer than the perianth.

J. austrobrasiliensis

4'. Flower heads stramineous, greenish or light castaneous, sometimes with reddish tinge.

6. Outer tepals conspicuously longer than the inner ones.

J. densiflorus

6 '. Outer tepals more or less equalling the inner ones, sometimes slightly longer or shorter.

J. micranthus

3'. Plants densely caespitose with a very short rhizome, or rhizome short and densely branched or shortly horizontal, with internodes abbreviated.

7. Capsule conspicuously longer than the perianth.

J. debilis

7'. Capsule shorter than, as long as, or slightly longer than the perianth.

8. Tepals light brown to greenish; capsule subeaqual to slightly exceeding the perianth.

8'. Tepals castaneous to brown; capsule shorter than the perianth. 
9. Capsule obtuse.

J. ernesti-barrosii

9'. Capsule more or less acute.

J. burkartii

2'. Stamens usually 6.

10. Inflorescence usually 1 headed, rarely $2-3$ headed, $2-5(-8)$-flowered each.

11. Lower bract usually exceeding the inflorescence; tepals longer than $3.5 \mathrm{~mm}$; style $0.7-1.5$ $\mathrm{mm}$ long.

J. scheuchzerioides

11 '. Lower bract usually slightly shorter than the inflorescence; tepals shorter than $3.5 \mathrm{~mm}$; style to $0.7 \mathrm{~mm}$ long.

J. stipulatus

$10^{\prime}$. Inflorescence 2 or more headed, or if 1 -headed then more than 11-flowered.

12. Plants densely caespitose; rhizome very short or short and densely branched.

13. Capsule shorter than the perianth.

14. Flower head peduncles $0.45 \mathrm{~mm}$ thick or thicker; tepals rigid.

J. pallescens

14'. Flower head peduncles $0.4 \mathrm{~mm}$ thick or thinner; tepals soft.

J. microcephalus

$13^{\prime}$. Capsule exceeding to much exceeding the perianth.

15. Capsule light castaneous, rostrum $0.6-1.0 \mathrm{~mm}$ long; inflorescence 8-16-headed, heads globose, 5-20-flowered, $8-11 \mathrm{~mm}$ in diam., flower pedicels to $1.5 \mathrm{~mm}$ long; inner tepals obtuse.

J. andersonii

15 '. Capsule castaneous to dark brown, rostrum to $0.5 \mathrm{~mm}$ long; inflorescence 6-55-headed, heads obpyramidal to hemispheric, 4-10-flowered, $3-9 \mathrm{~mm}$ in diam., flower pedicels to ca. $0.5 \mathrm{~mm}$ long; inner tepals acute to subobtuse.

J. articulatus

12 '. Plants loosely caespitose; rhizome long, creeping.

16. Style ca. $1 \mathrm{~mm}$ long.

J. diemii

16 '. Style $0.1-0.5 \mathrm{~mm}$ long.

J. llanquihuensis

Specimens examined. ARGENTINA. Prov. Neuquén: Confluencia, Centenario, Balneario municipal, 29-XII-2016, Jocou \& Minué 2313 (ARC). Prov. Río Negro: General Roca, Allen, 12-XII-2018, Jocou et al. 2314 (ARC); Cinco Saltos, 3-II-2020, Jocou 2318 (ARC); Cipolletti, 12-XII-2018, Jocou et al. 2315 (ARC); General Fernández Oro, 9-I-2020, Jocou 2316 (ARC); General Fernández Oro, 9-I2020, Jocou 2317 (ARC).
Additional specimens examined. CANADA. Prov. British Columbia: Vancouver Island, near Lake Shawnigan, 18-VIII-1897, Canby et al. 304 (US). Prov. Prince Edward Island: Prince, Wellington, 26-VII-1952, Erskine 1386 (P). Prov. Ontario: Thunder Bay, Mouth of Pine River on Lake Superior, Crooks Township, 22-VIII-1952, Garton 2205 (P). FINLAND. Áland: Lemland, Järsö, recreation area, NE corner of Söderfijärden, 


\section{A. I. Jocou and N. F. Brignone - Juncus articulatus in the Southern Cone}

06-VIII-1991, Lampinen \& Lampinen 13455 (SI). Northern Ostrobothnia: Pyhäjärvi, Keliä, in ripa lac., 19-VIII-1934, Lindberg s. n. (P). UNITED STATES. (s. d.), damp bare grounds, 18531856, Wright s. n. (US). St. Washington: Clark, Ridgefield National Wildlife Refuge, East side Tour Rd., 7-XII-2016, Maze CN254 (WTU); Franklin, Hanford National Wildlife Refuge, Wahluke Unit Parking Area 4, 17-IX-2015, Giblin 5749 (WTU); Island, Deception Pass State Park, Cranberry Lake, East and southeast shoreline of lake, 24-VIII-2010, Giblin et al. 3589 (WTU); Jefferson, Crocker Lake at Washington Departament of Fish and Wildlife access area near boat ramp, 24-VIII-2018, Giblin 6342 (WTU); Kittitas, Puget Sound Energy Wild Horse Wind Facility, south of Wild Horse Spring, North Fork Whiskey Dich Creek watershed, 14VII-2014, Bockelman 14-097 (WTU); Mason, Dewatto River Road, approximately $1 \mathrm{~km}$ North of intersection with Dewatto Beach Road, 24-VIII2015, Giblin et al. 5669 (WTU); Okanogan, Forest Road 39 (Toates Coulee Road), 6.2 air km, SW of Quartz Mountain, 16-VIII-2014, Zika 26774 (WTU). SPAIN. SEGOVIA: Caballar, El Guijar, 21-VIII-1988, Egido \& García 6120 (P).

\section{Author Contributions}

Photos from Figs. 2-4 from AIJ. NFB prepared Fig. 1; AIJ prepared Figs. 2-4. AIJ collected the specimens and analysed the data. Both authors wrote and reviewed the manuscript equally, agreed for the author's own contributions, and approved the submitted version.

\section{ACKNOWLEDgements}

We thank the reviewers and the associate editor for their valuable comments that allowed improve this manuscript. We deeply appreciate R. Gandullo (ARC, Universidad Nacional del Comahue) for his unconditional help during field work. We thank A. Suárez (SI) for her assistance with the herbarium specimens. We also thank R. Bijmoer (L) for providing us the high-quality image of the lectotype. Special thanks go to C. Romero Zarco (Universidad de Sevilla) for his relevant recommendations when examining Juncus specimens.

\section{BIBLIOGRAPHY}

BALSLEV, H. 1996. Juncaceae. Flora Neotropica 68: 1-167. http://www.jstor.org/stable/4393863

BALSLEV, H. 2018. Two new species of Juncus (Juncaceae) from South America. Phytotaxa 375: 97-102. https://doi.org/10.11646/phytotaxa.376.2.3

BARROS, M. 1945. Juncáceas argentinas. Holmbergia 4: 101-112.

BARROS, M. 1953. Las Juncáceas de la Argentina, Chile y Uruguay. Darwiniana 10: 279-460.

BARROS, M. 1969. Juncaceae. En: CORREA, N. M. (Dir.) Flora Patagónica, Parte II: Typhaceae a Orchidaceae (excepto Gramineae), pp. 109-137. INTA, Buenos Aires.

BAUHIN, C. 1620. Prodromos theatri botanici. Typis Pauli Jacobi, Frankfurt on the Main [online]. Available in: http://bibdigital.rjb.csic.es/ing/Libro. php?Libro=1441

BAUHIN, C. 1658. Theatri botanici. Ioannem König, Basel. https://doi.org/10.5962/bhl.title.7128

BROOKS, R. E. \& S. E. CLEMANTS. 2000. Juncus. In: FLORA OF NORTH AMERICA EDITORIAL COMMITTEE (eds.), Flora of North America 22, pp. 211-255. Oxford University Press, New York.

DRÁBKOVÁ, L., J. KIRSCHNER \& Č. VLČEK. 2006. Phylogenetic relationships within Luzula DC. and Juncus L. (Juncaceae): a comparison of phylogenetic signals of trnL-trnF intergenic spacer, $\operatorname{trn} L$ intron and $r b c L$ plastome sequence data. Cladistics 22: 132-143. https://doi.org/10.1111/j.1096-0031.2006.00095.x

FERNÁNDEZ, C. J., A. I. JOCOU \& R. GANDULLO. 2018. Vegetación acuática bioindicadora de eutrofización del Alto Valle de Río Negro (Argentina). Ernstia 28: 45-93.

FERRER-GALLEGO, P. P. 2019. Typification of four Linnaean names in the genus Juncus (Juncaceae). Taxon 68: 142-151. https://doi.org/10.1002/tax.12013

GANDULLO, R., C. FERNÁNDEZ \& A. I. JOCOU. 2019. Sintaxonomía de las comunidades de plantas vasculares del sistema de drenaje del Alto Valle de Río Negro, Patagonia, Argentina. Bol. Soc. Argent. Bot. 54: 567-587. https://doi.org/10.31055/1851.2372.v54.n4.24826

GEOFFREY, R., B. SMITH \& M. A. BROCK. 1996. Coexistence of Juncus articulatus L. and Glyceria australis C. E. Hubb. in a temporary shallow wetland in Australia. Hydrobiologia 340: 147-151. https://doi.org/10.1007/978-94-011-5782-7_23 
GRIME J. P., J. G. HODGSON \& R. HUNT. 1988. The Autecological Accounts. In: GRIME, J. P., J. G. HODGSON \& R. HUNT, Comparative Plant Ecology, pp. 53-615. Springer, Dordrecht. https://doi.org/10.1007/978-94-017-1094-7_5

GUOFANG, W. \& S. E. CLEMANTS. 2000. Juncaceae. In: WU, Z. Y. \& P. H. RAVEN (eds.) Flora of China 24, pp. 44-69. Science Press, Beijing, and Missouri Botanical Garden Press, St. Louis.

JOCOU, A. I. \& R. GANDULLO. 2018. Primer registro de Epilobium hirsutum (Onagraceae) para la flora Argentina. Darwiniana, n. s. 6: 99-107. https://doi.org/10.14522/darwiniana.2018.61.784

JOCOU, A. I. \& R. GANDULLO. 2020. Diversidad de plantas vasculares de los humedales de la Norpatagonia (Argentina). Rev. Mus. Argentino Cienc. Nat. 22: 131-154. https://doi.org/10.22179/REVMACN.22

JOCOU, A. I., C. FERNÁNDEZ \& R. GANDULLO. 2018. Macrófitas acuáticas vasculares del sistema de drenaje del Alto Valle de Río Negro, Patagonia (Argentina). Revista Mus. La Plata 3: 296-308. https://doi.org/10.24215/25456377e060

JOCOU, A. I., C. R. MINUÉ, N. F. BRIGNONE \& R. GANDULLO. 2020. Going unnoticed for 40 years: about the presence of the exotic Suaeda paradoxa (Chenopodiaceae, Suaedoideae) in Argentina. Phytotaxa 450: 219-228.

https://doi.org/10.11646/phytotaxa.450.2.7

KIRSCHNER, J. 2002a. Juncaceae 1: Rostkovia to Luzula, Species Plantarum: Flora of the World 6. Australian Biological Resources Study (ABRS), Canberra, Australia.

KIRSCHNER, J. 2002b. Juncaceae 2: Juncus subg. Juncus, Species Plantarum: Flora of the World 7. Australian Biological Resources Study (ABRS), Canberra, Australia.

MORISON, R. 1699. Plantarum historiae universalis Oxoniensis, vol. 3. Theatro Sheldoniano, Oxford [online]. Available in: http://bibdigital.rjb.csic.es/ spa/Libro.php?Libro=5556

NILSSON, O. \& S. SNOGERUP. 1972. Drawings of Scandinavian plants 69 - 74: Juncus L. Bot. Not. 125: 131-138. https://doi.org/10.3109/01050397309044945

NOVARA, L. J. 2009. Juncaceae. En: KIESLING, R. (Dir.) Flora de San Juan, Vol. IV: Monocotiledóneas, pp. 377-391. Zeta Editores, Mendoza.
PYŠEK, P., D. M. RICHARDSON, M. REJMÁNEK, G. L. WEBSTER, M. WILLIAMSON \& J. KIRSCHNER. 2004. Alien plants in checklists and floras: towards better communication between taxonomists and ecologists. Taxon 53: 131-143. https://doi.org/10.2307/4135498

QGIS DEVELOPMENT TEAM. 2020. QGIS Geographic Information System. Open Source Geospatial Foundation Project. https://qgis.org, accessed 2 August 2020.

ROBERTS, J. \& F. MARSTON. 2000. Water regime of wetland and floodplain plants in the MurrayDarling Basin. CSIRO Land and Water, Canberra.

ROMERO ZARCO, C. 2010. Juncus. In: TALAVERA, S., M. J. GALlEGO, C. ROMERO ZARCO \& A. HERRERO (eds.) Flora Iberica: Plantas vasculares de la Península Ibérica e Islas Baleares 17, pp. 123-187. CSIC, Madrid.

SMITH, R. G. B. \& M. A. BROCK. 1997. Germination potential, growth patterns and reproductive effort of Juncus articulatus and Glyceria australis in temporary shallow wetlands in Australia. Wetlands Ecol. Managem. 5: 203-214. https://doi.org/10.1023/A:1008268202984

STEVENS, P. F. 2001, onwards. Angiosperm Phylogeny Website. Version 14, July 2017 [and more or less continuously updated since].

THIERS, B. continuously updated. Index Herbariorum: a global directory of public herbaria and associated staff. New York Botanical Garden's Virtual Herbarium. http://sweetgum.nybg.org/ science/ih

THOMÉ, O. W. 1886. Flora von Deutschland, Österreich und der Schweiz in Wort und Bild für Schule und Haus, Band 1. verlag von Fr. Eugen Köhler, Untermhaus [online]. Available in: https:// www.biodiversitylibrary.org/item/194265

VOGT, K., L. RASRAN \& K. JENSEN. 2004. Waterborne seed transport and seed deposition during flooding in a small river-valley in Northern Germany. Flora 199: 377-388. https://doi.org/10.1078/0367-2530-00166

ZULOAGA, F. O., J. M. BELGRANO \& C. A. ZANOTTI. 2019. Actualización del Catálogo de las Plantas Vasculares del Cono Sur. Darwiniana, nueva serie 7: 208-278. https://doi.org/10.14522/darwiniana.2019.72.861 